Nippon Suisan Gakkaishi $\quad$ 75(1), 64-69 (2009)

\title{
ブリ（当歳魚）の成長と脂質代謝における 色落ちノリ添加飼料の効果
}

深田陽久, *田所大二, 古谷尚大, 好井覚大，森岡 克司，益本俊郎

(2008 年 7 月 9 日受付, 2008 年 9 月 22 日受理)

高知大学農学部

Effect of discolored Porphyra meal supplemented-diet on growth performance and lipid metabolism in yearling yellowtail (Seriola quinqueradiata)

\section{HARUHISA FUKADA,* DAIJI TADOKORO, TAKAHIRO FURUTANI, KAKUTA YOSHII, KATSUJI MORIOKA AND TOSHIRO MASUMOTO}

Faculty of Agriculture, Kochi University, Nankoku, Kochi 783-8502, Japan

For the beneficial use of discolored Porphyra yezoensis (purple laver), we investigated the effects of adding Porphyra meal to diet on the growth performance and lipid metabolism in yearling yellowtail Seriola quinqueradia$t a$. Yearling yellowtails were fed extruded pellets containing 0,2 , or $4 \%$ of Porphyra meal for 40 days. The growth performance (i.e., feed efficiency, protein efficiency ratio, and specific growth rate) did not differ significantly among the dietary groups; however, the performance was slightly higher in the $2 \%$ Porphyra meal-supplemented diet group and slightly lower in the $4 \%$ Porphyra meal-supplemented diet group. In the liver, the lipogenic enzyme activity increased in the $4 \%$ Porphyra meal-supplemented diet group and the hepatic gluconeogenic enzyme activity significantly increased in all the Porphyra meal-supplemented diet groups. In the $2 \%$ Porphyra meal-supplemented diet group, enzyme activity related to fatty acid oxidation was slightly higher in the liver and significantly higher in the dark muscle. These results indicated that the addition of Porphyra meal to fish feed affects lipid metabolism in yearling yellowtail.

キーワード : 色落ちノリ, 脂質代謝, 飼料, 成長, 代謝酵素, ブリ

ノリPorphyra yezoensis は日本の食生活において重要 な食品であるが，近年，日本各地で多量の「色落ちノリ」 と呼ばれる低品質のノリが発生し, 深刻な問題となって いる。色落ちノリは外見上, 通常のノリと比較して黒み が乏しく, タンパク質含量やアミノ酸含量が低く食用に 適さない。そのため買い手がつかず, 落札されないまま 破棄されてしまう。今後も色落ちノリは発生し続けると 考えられるため, 色落ちノリの有効利用の検討が必要で ある。

これまで, 魚類において藻類や藻類抽出物の養魚飼料 への添加効果が確認されており, 抗病性の増大, ${ }^{1)}$ ス卜 レス耐性, ${ }^{2-5)}$ タンパク質効率の向上, ${ }^{4-6)}$ 絶食期間中の 体重減少の抑制, ${ }^{2,3}$ さらに脂質代謝に打いて脂質蓄積の 調整や脂質のエネルギーへの転換能の向上 ${ }^{2,3)}$ が認めら
れている。これらのことから, 色落ちノリの有効利用方 法の一つとして養魚飼料への添加があげられる。

ブリ Seriola quinqueradiataを用いた研究でも, コン ブ粉末や不稔性アオサ等の藻類を飼料に添加することに より, 飼料効率やタンパク質効率の改善, 脂質蓄積の増 大をたは抑制, 脂質のエネルギー転換能の改善等が観察 されている。 ${ }^{7-9)} こ れ ら の$ 効果には, 脂質の代謝が深く 関わっていると考えられる。魚類の中でもブリの様な魚 食性の魚は, その生命活動のエネルギ一源としてタンパ ク質または脂質を利用している。10) そのため, ブリの配 合飼料は魚粉と魚油を主成分として製造されている。10) 主タンパク源である魚粉は比較的高価であり，またタン パク質がエネルギー源として用いられた場合, 窒素排泄 物が増加し環境負荷を増大させてしまう。そのため, タ

* Tel and Fax : 81-88-864-5156. Email : fukaharu@kochi-u.ac.jp 
ンパク源が不必要にエネルギー源として利用されること

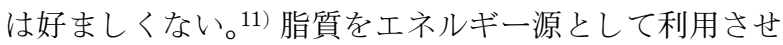
ることによって, 飼料効率やタンパク質効率の改善等が 可能となり，養魚の成長を促すことが可能になると思わ れる。脂質の利用性には, 脂質代謝系酵素が深く関わっ ている。魚類に打ける脂質 (脂肪酸) 合成系酵素として, ペントースリン酸回路の phosphogluconate dehydrogenase (PGDH) 打よび glucose-6-phosphate dehydrogenase $(\mathrm{G} 6 \mathrm{PDH})$ が知られている。これらの酵素 は飼料の脂質含量や糖質添加によって影響を受けること がブリに捛いて報告されている。12-14) 脂質（脂肪酸）分 解系酵素としては，ミトコンドリアのマトリクス内に存 在する carnitine palmitoyltransferase (CPT) や carnitine palmitoyltransferase II (CPTII) が脂肪酸の $\beta$-酸化 に関わって抢り, 15,16) 魚類の palmitoyl-L-carnitine や遊 離脂肪酸の $\beta$-酸化活性は肝臓より血合筋で高いことが 大西洋サケSalmo salar, 16) ニジマス Oncorhynchus mykiss ${ }^{17)}$ 抢よび大西洋サバ Scomber scombrus ${ }^{18)}$ で確認 されている。

そこで, 本研究では飼料への色落ちノリ添加が肝蔵の 脂肪酸合成系酵素（G6PDH おちよび PGDH） と肝臓と血 合筇に抢ける脂肪酸分解系酵素（CPTII）の活性に与え る影響に着目した。また，脂質からエネルギーが産生さ れていることを確認するため, 脂質代謝系酵素に加えて 糖代謝系酵素々アミノ酸系代謝酵素についても併せて測 定を行い，色落ちノリ添加飼料がブリ当歳魚の成長と脂 質代謝へ与える影響を観察することを目的として試験を 行った。

\section{材料および試験方法}

試験飼料 各試験飼料の配合組成および一般成分を Table 1 に示す。本研究では, 沿岸魚粉を主タンパク質 源とし，小麦粉，デンプン，大豆油粕，コーングルテン ミールおよび魚油等からなる飼料を基本飼料とした。色 落ちノリ（乾燥スサビノリPorphyra yezoensi 粉末）は, 外割りで 0,2 , 抢よび $4 \%$ で添加した。各飼料（直径 $6 \mathrm{~mm}$, 長さ $5 \mathrm{~mm}$ ）は日本農産工業陎（横浜）にて, 二軸エクストルーダー (形式 DNDG-62 型, ビューラー 社，スイス）を用いて成型した。

全試験飼料の水分，灰分抢よび粗タンパク質含量は AOAC 法 (AOAC 1995) ${ }^{19)}$ で，粗脂肪含量は，メタノー ル・クロロホルム抽出法 ${ }^{20)}$ にっって測定した。粗タン パク質含量は約 $41 \%$, 粗脂肪含量は約 $21 \%$ ，粗灰分含 量は約 $9 \%$ と類似していた。

供試魚および飼育方法 供試魚には，2007 年に高知 県土佐湾沖で採補され，試験開始まで市販の EP 飼料で 予備飼育したブリ当歳魚を用いた。その中から選抜した 平均体重 $243 \mathrm{~g}$ のブリを 6 つの 1 トン容 FRP 製円形水
Table 1 Ingredients and proximate composition of the experimental diets

\begin{tabular}{|c|c|c|c|}
\hline Ingredients $(\%)$ & Control & Porphyra $2 \%$ & Porphyra 4\% \\
\hline Fish meal & 51.1 & 51.1 & 51.1 \\
\hline Porphyra meal & - & 2.0 & 4.0 \\
\hline Fish oil & 19.0 & 19.0 & 19.0 \\
\hline Wheat flour & 12.0 & 12.0 & 12.0 \\
\hline Soybean meal & 5.0 & 5.0 & 5.0 \\
\hline Corn gluten meal & 5.0 & 5.0 & 5.0 \\
\hline$\alpha-\operatorname{starch}$ & 5.0 & 5.0 & 5.0 \\
\hline Vitamin mix & 1.6 & 1.6 & 1.6 \\
\hline Mineral mix & 1.3 & 1.3 & 1.3 \\
\hline Total & 100.0 & 102.0 & 104.0 \\
\hline \multicolumn{4}{|l|}{ Composition (\%) } \\
\hline Crude protein & 41.3 & 42.6 & 39.4 \\
\hline Crude lipid & 21.1 & 20.5 & 22.7 \\
\hline Moisture & 8.4 & 7.1 & 11.0 \\
\hline Ash & 9.2 & 9.7 & 9.0 \\
\hline
\end{tabular}

Vitamin mix and mineral mix were added according to the instructions of NOSAN Corp.

槽に 18 尾ずつ収容した。色落ちノリを 0,2 および $4 \%$ 添加した飼料を給餌する試験区をそれぞれ対照区，色落 ちノリ添加 $2 \%$ 区および色落ちノリ添加 $4 \%$ 区とし た。飼育試験は二重試験区で行った。

試験期間中，供試魚には各試験飼料を 1 日 1 回，総 魚体重に対して $3 \%$ の量で給与した。給餌量は，10 日 ごとの魚体重測定の結果に基づいて調整した。試験期間 中の水温打よび溶存酸素量はそれぞれ，23.6〜 $26.6^{\circ} \mathrm{C}$ 打 よび 4.66〜 $6.20 \mathrm{mg} \mathrm{L}^{-1}$ で推移した。以上の飼育試験は すべて, 高知県香南市赤岡町のヒラメ養殖施設にて行っ た。

試料の採取 開始時, 10, 20, 30 および終了時の 40 日目に，各試験区の総魚体重を測定した。試験開始 20 日目抢よび 40 日目には各試験水槽から 5 尾ずつ無作為 に取り出し，血液を得た。採血後，その 5 尾よりフィ レー（左半身）および肝臓を採取し，一般成分分析に供 した。酵素活性分析のために, 右半身の血合筋と先に採 取した肝臓から肝臓片を得た。一般成分分析用試料と酵 素活性用試料は，分析時までそれぞれ $-20^{\circ} \mathrm{C}$ と $-80^{\circ} \mathrm{C}$ で保存した。

成長成績および飼料効率 魚体重および給䬣量に基づ いて試験終了時の生存率，飼料効率，日間給䭒率，日間 成長率, タンパク質効率, 肥満度抢よび比肝重值を算出 した。

血清成分 血清成分として総タンパク質, グルコー ス，総コレステロールおよびトリグリセリド濃度を， DRI-CHEM3500V（富士フィルム秼，東京）で測定し 
た。

フィレー, 肝臟および飼料の一般成分 フィレーおよ び肝蔵は, 各試験水槽から採取した 5 尾分をホモジナ イズし，プールしたものを 1 試料として一般成分分析 に供した。フィレーおよび肝蔵における水分, 粗タンパ ク質, 粗脂肪抢よび粗灰分含量は AOAC 法（AOAC 1995）により測定した。 ${ }^{19)}$

\section{代謝酵素活性の測定}

\section{1. 酵素液の調整}

脂質分解系酵素（CPTII）測定用 肝臓または血合筋 を量りとり，9 倍量のホモジナイズ用緩衝液 $(0.25 \mathrm{M}$ sucrose, 1 mM EDTA, 3 mM Tris-HCl, pH 7.2) を加え た後にホモジナイズした。その後, $4{ }^{\circ} \mathrm{C}, 500 \times g$ で 15 分間遠心した。上清 $500 \mu \mathrm{L}$ を $1.5 \mathrm{~mL}$ マイクロチュー ブにとり，ホモジナイズ用緩衝液を $1000 \mu \mathrm{L}$ 加えて擋 找し, $4{ }^{\circ} \mathrm{C}, 14000 \times g$ で 10 分間遠心分離した。遠心 後, 上清を捨て, ホモジナイズ用緩衝液を $1000 \mu \mathrm{L}$ 追 加して擋拌し, $4{ }^{\circ} \mathrm{C}, 14000 \times g$ で 10 分間遠心分離し た。上清を捨てた後に沈澱を $500 \mu \mathrm{L}$ のホモジナイズ用 緩衝液を加えて, 擋挥し, これをCPTII 活性測定用粗 酵素液とした。粗酵素溶液のタンパク質濃度は, ウシ血 清アルブミンをスタンダードとして BCA protein assay kit (Pierce, USA) を用いて決定した。

脂質分解系 (CPTII) 以外の酵素活性測定用 サンプ ルを試験管に量りとり，9 倍量のホモジナイズ用緩衝液 でホモジナイズし，その後 $15000 \times g$ で 20 分間遠心分 離をした。上清を回収し、これを粗酵素液とした。粗酵 素溶液のタンパク質濃度は, 上述の方法で測定した。

\section{2. 各酵素の測定方法}

Carnitine palmitoyltranferase II (CPTII, EC 2.3.1.21), Phosphofructokinase (PFK, EC 2.7.1.11), Fructose-1,6-bisphosphate (FBPase, EC 3.1.3.11), Glucose-6-phosphate dehydrogenase (G6PDH， EC 1.1.1.49) 打よび 6-phosphogluconate dehydrogenase （PGDH, EC 1.1.1.44）は既報の方法21-23) に従って測定し た。吸光度の測定には UV-1600（侏島津製作所, 京都)

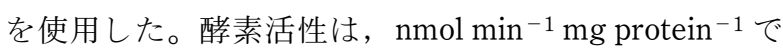
表した。

Aspartate aminotransferase (AST, EC 2.6.1.1) 打よ び Alanine aminotransferase (ALT, EC 2.6.1.2) AST お よび ALT の活性は市販の臨床検査用キット（トランス アミナーゼ CII-テストワコー, 和光純薬工業侏 (大阪)) を用いて測定した。酵素活性は測定条件下で 1 分間に おける基質または補酵素の変化量を nmol で表し, タン パク質 $1 \mathrm{mg}$ あたりの活性として表した。

統計処理 得られた值は全て GraphPad Prism ver.4.0 (Graphpad software, Inc., CA, USA) を用いて，一元配
置の分散分析に引き続き, チューキーの多重比較検定を 行い，危険率 $5 \%$ に抢ける有意差を判定した。

\section{結果}

成長成績および飼料効率 試験終了時の成長成績を Table 2 に示した。全試験区で弊死魚は無かった。平均 体重, 飼料効率, タンパク質効率, 日間成長率打よび日 間給餌率に関して, 試験区間で有意差はみられなかった が, 色落ちノリ $2 \%$ 添加区が最も高值を示し, 色落ち ノリ $4 \%$ 添加区が最も低值であった。比肝重值は全て の試験区間で有意差は無かったが, 色落ちノリ $2 \%$ 添 加区が他の試験区より低い值を示した。肥満度は全ての 試験区間で有意差は無かった。

フィレーおよび肝臓の一般成分 試験終了時のフィ レーおよび肝臓の一般成分を Table 3 に示した。フィ レーおよび肝蔵の一般成分に有意な差はなかったが，他 の試験区と比較して, 色落ちノリ $2 \%$ 添加区で粗脂肪 含量が低かった。

血清成分 試験開始 20 日目の測定結果は各試験区間 で有意な差がみられなかったため, 試験終了時の血清成 分の濃度のみを Table 4 に示した。総タンパク質濃度抒 よびトリグリセライド濃度は, 全ての試験区間で有意な 差は無かった。グルコース濃度は, 有意差は認められな かったものの, 色落ちノリ添加によって増加する傾向が

Table 2 Growth performance and feed efficiency of yearling yellowtail fed the experimental diets

\begin{tabular}{|c|c|c|c|}
\hline & \multicolumn{3}{|c|}{ Dietary group } \\
\hline & Control & Porphyra $2 \%$ & Porphyra $4 \%$ \\
\hline Initial body weight $(\mathrm{g})$ & $244.7 \pm 5.6$ & $243.5 \pm 5.8$ & $241.1 \pm 4.6$ \\
\hline Final body weight (g) & $373.6 \pm 6.6$ & $380.7 \pm 2.6$ & $359.1 \pm 4.6$ \\
\hline Feed efficiency $(\%) * 1$ & $72.3 \pm 4.7$ & $75.2 \pm 0.9$ & $70.0 \pm 0.5$ \\
\hline Protein efficiency ratio $* 2$ & $1.60 \pm 0.10$ & $1.69 \pm 0.03$ & $1.58 \pm 0.01$ \\
\hline $\begin{array}{l}\text { Specific growth rate } \\
\left(\% \text { day }^{-1}\right) * 3\end{array}$ & $1.06 \pm 0.05$ & $1.12 \pm 0.02$ & $1.00 \pm 0.00$ \\
\hline $\begin{array}{l}\text { Daily feed intake } \\
\left(\% \text { bw day }{ }^{-1}\right)^{* 4}\end{array}$ & $1.60 \pm 0.04$ & $1.62 \pm 0.01$ & $1.56 \pm 0.01$ \\
\hline Hepatosomatic index $(\%) * 5$ & $1.20 \pm 0.07$ & $1.10 \pm 0.05$ & $1.20 \pm 0.08$ \\
\hline Condition factor $* 6$ & $1.73 \pm 0.02$ & $1.78 \pm 0.03$ & $1.71 \pm 0.04$ \\
\hline Survival rate ${ }^{* 7}$ & $100 \pm 0.00$ & $100 \pm 0.00$ & $100 \pm 0.00$ \\
\hline
\end{tabular}

Values are mean $\pm \mathrm{SE}$ of duplicate tanks (feed efficiency, protein efficiency ratio, daily feeding rate and survival rate), 10 fish (hepatosomatic index and condition factor) or 18 fish (final body weight).

*1 $\mathrm{g}$ wet weight gain $/ \mathrm{g}$ feed intake $\times 100$.

*2 $\mathrm{g}$ wet weight gain/g protein intake.

*3 [ln (g final average body weight) $-\ln (\mathrm{g}$ initial average body weight) $]$ /days.

*4 $100 \times \mathrm{g}$ feed intake/[ (initial fish number + final fish number) $/ 2 \times$ ( $\mathrm{g}$ initial average body weight $+\mathrm{g}$ final average body weight) $/ 2] /$ feeding days.

*5 $\mathrm{g}$ individual liver weight/g individual body weight.

*6 $100 \times$ [g individual body weight / $(\mathrm{cm} \text { individual fork length })^{3}$ ].

*7 $100 \times$ (final fish number/initial fish number). 
Table 3 Proximate composition of filet and liver of yearling yellowtail fed the experimental diets

\begin{tabular}{llll}
\hline & \multicolumn{3}{c}{ Dietary group } \\
\cline { 2 - 4 } & Control & Porphyra 2\% & Porphyra 4\% \\
\hline Filet (\%) & & & \\
Moisture & $68.1 \pm 0.1$ & $69.1 \pm 0.0$ & $69.1 \pm 0.3$ \\
Protein & $21.5 \pm 0.0$ & $22.3 \pm 0.1$ & $22.2 \pm 0.4$ \\
Lipid & $9.80 \pm 0.22$ & $9.05 \pm 0.16$ & $9.72 \pm 0.63$ \\
Ash & $1.62 \pm 0.00$ & $1.51 \pm 0.03$ & $1.64 \pm 0.11$ \\
Liver (\%) & & & \\
Moisture & $57.1 \pm 3.4$ & $58.7 \pm 0.4$ & $57.3 \pm 3.3$ \\
Protein & $11.2 \pm 0.0$ & $12.1 \pm 0.0$ & $10.7 \pm 0.4$ \\
Lipid & $25.1 \pm 1.7$ & $22.8 \pm 2.5$ & $26.0 \pm 0.72$ \\
Ash & $1.72 \pm 0.02$ & $1.56 \pm 0.06$ & $1.48 \pm 0.44$ \\
\hline
\end{tabular}

Values are mean \pm SE of duplicate tanks.

Table 4 Serum total protein, glucose, triglyceride and total cholesterol levels of yearling yellowtail fed the experimental diets

\begin{tabular}{|c|c|c|c|}
\hline & \multicolumn{3}{|c|}{ Dietary group } \\
\hline & Control & Porphyra $2 \%$ & Porphyra 4\% \\
\hline $\begin{array}{l}\text { Total protein } \\
\left(\mathrm{g} 100 \mathrm{~mL}^{-1}\right)\end{array}$ & $3.50 \pm 0.15$ & $3.30 \pm 0.25$ & $3.84 \pm 0.13$ \\
\hline $\begin{array}{l}\text { Glucose } \\
\left(\mathrm{mg} 100 \mathrm{~mL}^{-1}\right)\end{array}$ & $125.2 \pm 10.6$ & $134.1 \pm 11.1$ & $159.0 \pm 11.3$ \\
\hline 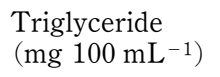 & $122.3 \pm 6.1$ & $115.7 \pm 7.2$ & $129.9 \pm 11.6$ \\
\hline $\begin{array}{l}\text { Total cholesterol } \\
\left(\mathrm{mg} 100 \mathrm{~mL}^{-1}\right)\end{array}$ & $242.0 \pm 8.9^{\mathrm{a}}$ & $238.3 \pm 15.3^{\mathrm{a}}$ & $286.2 \pm 8.1^{\mathrm{b}}$ \\
\hline
\end{tabular}

Values (mean $\pm \mathrm{SE}$ of 10 fish) in the same line not sharing a common superscript letter are significantly different $(P<0.05)$.

みられた。総コレステロール量は，色落ちノリ添加 4 \%区で他の試験区に対して有意な高値を示した。

代謝酵素活性 試験開始 20 日目の測定結果は各試験 区間で有意な差がみられなかったため，試験終了時 （40 日目）の代謝酵素活性の久を Table 5 に示した。

1. 解糖系および糖新生系 肝臓 PFK 活性は, 色落 ちノリ添加区で対照区より高值を示したが，有意差は無 かった。肝蔵 FBPase 活性は, 両色落ちノリ添加区で対 照区より有意に高い值を示した。

2. 脂質合成系酵素 肝臓の PGDH 活性は，ノリ添 加割合とともに増加し，色落ちノリ添加 $4 \%$ 区は対照 区に対して有意に高かった。G6PDH 活性は，PGDH 活 性と同様にノリ添加割合の増加によって上昇し，色落ち ノリ添加 4\%区では対照区と色落ちノリ添加 $2 \%$ 区に 対して有意な高值を示した。

3. 脂質分解系酵素 肝臓 CPTII 活性は，全試験区 間で有意な差は見られなかったが，色落ちノリ添加 2 \%区で最も高值を示した。血合筋 CPTII 活性では，色
Table 5 Metabolic enzyme activities of yearling yellowtail fed the experimental diets

\begin{tabular}{lccc}
\hline \multirow{2}{*}{$\begin{array}{c}\text { Enzyme activity } \\
\text { (nmol min }\end{array}$ mg protein $\left.^{-1}\right)$} & \multicolumn{3}{c}{ Dietary group } \\
\cline { 2 - 4 } & Control & Porphyra 2\% & Porphyra $4 \%$ \\
\hline PFK & $5.17 \pm 0.34$ & $6.08 \pm 0.55$ & $5.90 \pm 0.74$ \\
FBPase & $28.6 \pm 1.6^{\mathrm{a}}$ & $37.7 \pm 2.1^{\mathrm{b}}$ & $39.6 \pm 2.1^{\mathrm{b}}$ \\
PGDH & $38.2 \pm 5.7^{\mathrm{a}}$ & $44.7 \pm 3.8^{\mathrm{ab}}$ & $58.3 \pm 5.3^{\mathrm{b}}$ \\
G6PDH & $32.8 \pm 8.6^{\mathrm{a}}$ & $43.8 \pm 6.4^{\mathrm{a}}$ & $84.7 \pm 14.4^{\mathrm{b}}$ \\
CPTII (liver) & $0.706 \pm 0.145$ & $1.070 \pm 0.240$ & $0.696 \pm 0.070$ \\
CPTII (dark muscle) & $4.45 \pm 0.49^{\mathrm{ab}}$ & $5.22 \pm 0.81^{\mathrm{b}}$ & $2.22 \pm 0.42^{\mathrm{a}}$ \\
AST & $1093 \pm 107$ & $1076 \pm 125$ & $921 \pm 86$ \\
ALT & $751 \pm 43$ & $776 \pm 71$ & $716 \pm 48$ \\
\hline The enzyme activity of phosphofructokinase (PFK), fructose-1,6- \\
bisphosphate (FBPase), phosphogluconate dehydrogenase (PGDH), \\
glucose-6-phosphate dehydrogenase (G6PDH), aspartate amino- \\
transferase (AST), and alanine aminotransferase (ALT) in liver, \\
and carnitine palmitoyltransferase II (CPTII) in liver and muscle. \\
Values (mean \pm SE of 8-10 fish) in the same line not sharing a com- \\
mon superscript letter are significantly different $(P<0.05)$.
\end{tabular}

落ちノリ添加 $2 \%$ 区の活性が, 色落ちノリ添加 $4 \%$ 区 より有意に高くなった。

4. アミノ基転移酵素 肝臓の AST 活性とALT 活 性は，全試験区間で有意な差は認められなかったが，色 落ちノリ添加 $4 \%$ 区では, 他の試験区に比べて低い值 を示した。

\section{考察}

本試験では, 色落ちノリ添加飼料を与えたブリ（当歳 魚）の成長，体成分扔よび代謝酵素の変化を調べた。色 落ちノリ添加 $2 \%$ では, 平均体重, 増重率, 飼料効率 およびタンパク質効率が対照区に比べてわずかに改善さ れる傾向が見られたが，色落ちノリ添加 $4 \%$ 区では逆 に低下が認められた。藻類添加量の増加による成長への 影響は, 不稔性アオサを用いたブリ当歳魚の飼育試験に おいても観察されている。不稔性アオサ添加 $3 \%$ で は, 増重, 飼料効率扔よびタンパク質効率は対照区に対 して高くなった。しかしながら, 不稔性アオサ $6 \%$ 以 上の添加では，それらの項目は摂䬣率とともに著しく低 下した。藻類の添加割合に関して，同様の結果がアオサ 粉末を用いたクロダイAcanthopagrus schlegelii での飼 料効率やタンパク質効率でも観察されており, 至適添加 量は $2.5 〜 5 \%$ とされている。3) ブリにおける飼料への藻 類添加による摂䬣率扔よび成長の低下は, クロレラ抽出 物（1％）やコンブ粉末 (0.5\%) の添加でもみられて いる。 ${ }^{7)}$ これらのことから, 藻類の飼料への過㮃な添加 は摂䬣率の低下を引き起こし，その結果として成長が低 下すると考えられている。しかしながら，本研究では一 定量で給慨を行ったにも関わらず成長が低下したことか ら, 色落ちノリ添加による飼料の消化・吸収率の低下や 代謝の変化等の拱餌性以外の要因があると思われる。 
これまでブリ当歳魚と 1 歳魚において, 海藻類を飼 料に添加することによって筋肉中の脂肪含量が影響を受 けることが観察されている。7-9) コンブ粉末 $(0.5 \%)$ の 添加では脂質含量が増加し, 7 ) 不稔性アオサ (3\%) の 添加では減少した。8,9) また, 不稔性アオサの添加では, 脂質の蓄積が抑えられているにもかかわらず, 飼料効率 が高くなった。これらのことから, 海藻類がブリの脂質 代謝に影響を与えていると考えられてきた。本研究の色 落ちノリ添加 $2 \%$ 区では, フィレーと肝蔵の一般成分 分析で粗脂肪含量の低下が認められ, 飼料効率は他の 2 試験区より高かった。一方, 色落ちノリ $4 \%$ 添加区で のフィレーおよび肝臓の粗脂肪含量は, 対照区と同等で あったが，飼料効率は他の 2 試験区より低くなった。 代謝酵素に着目してみると, 脂肪酸合成酵素である $\mathrm{PGDH}$ および G6PDH が色落ちノリ添加 $4 \%$ 区で対照 区に対して有意に高い値を示していた。これらのことか ら, 色落ちノリ添加 $4 \%$ 区では, 他の 2 試験区に比べ て脂肪酸の分解よりも脂肪酸合成（脂質合成）が盛んで あると考えられる。血中の総コレステロール量が色落ち ノリ添加 $4 \%$ 区で上昇していることも脂質合成の活性 化を支持するものである。脂肪酸分解酵素である肝臓の CPTII 活性は, 色落ちノリ添加 $2 \%$ 区では対照区に比 べてやや高值を示し, 血合筋の CPTII 活性でも, 色落 ちノリ添加 $2 \%$ 区で高くなった。これらのことから， 色落ちノリ添加 $2 \%$ 区では, 脂肪酸の分解が促進され ていると考えられる。このような藻類による脂質代謝へ の影響はマダイ Pagrus major で観察されており, 飼料 中への藻類の一種であるスピルリナ添加（3\%）によっ て, G6PDH 活性がやや上昇し, CPT 活性が増加する ことが確認されている。15) その酵素活性の上昇要因とし て, スピルリナに含まれるビタミン C の効果が示唆さ れている。スサビノリにもビタミンC が含まれている ため, ${ }^{24)}$ 本試験の色落ちノリ $2 \%$ 添加区でも同様の効 果が得られたと考えられる。しかしながら，色落ちノリ $4 \%$ 添加区では, CPTII の活性が低下していることか ら, ブリに抢ける色落ちノリによる代謝酵素活性の変化 の要因についてはさらなる研究が必要である。上記の組 織中の粗脂肪含量と脂質代謝酵素活性を併せて考慮する と, 色落ちノリはブリ当歳魚の脂質代謝に影響を与える ことが明らかとなり，その作用は添加割合によって異な ると思われる。

これまでの研究に㧤いて, 飼料への藻類添加によって 飼料効率やタンパク質効率が改善する原因として, 脂質 がエネルギー源として有効に使われていることが考えら れている。 ${ }^{2-5)}$ 脂肪酸からエネルギーを産生するために 必要な経路である $\beta$-酸化に深く関わっている $\mathrm{CPTII}^{16)}$ の活性測定では, 肝臓と血合筋ともに色落ちノリ添加 2 $\%$ 区が他の 2 試験区よりも高值を示していた。グル
コースを生成する糖新生反応の律速酵素である FBPase の活性は, 色落ちノリ添加区で有意に高值を示していた。 Meton ら ${ }^{25)}$ の報告に従い, 糖新生系酵素（FBPase）活 性と解糖系酵素 (PFK) 活性比 (FBPase/PFK) を求 めると，対照区，ノリ添加 $2 \%$ 区抒よびノリ添加 $4 \%$ 区でそれぞれ，5.53, 6.20, 6.71 となった。このことか ら, 飼料中への色落ちノリ添加によって糖新生（グル コース生成）の流れが強くなることが示された。このこ とは, 血中のグルコース量が色落ちノリ添加割合に依存 して増加する傾向を示していることからも明らかであ る。また, アミノ基転移酵素である AST と ALT の肝 臓での活性は, 色落ちノリ添加 $2 \%$ 区では対照区とほ ぼ同一の值であったが, 色落ちノリ添加 $4 \%$ 区は対照 区より低い值を示した。AST とALTは, 飼料中のタ ンパク質含量に依存して活性が上昇し, 窒素の排泄量も

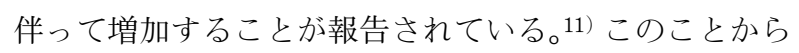
アミノ基転移酵素活性の上昇は, タンパク質からのエネ ルギー産生を意味するものと考えられる。色落ちノリ添 加の割合が $2 \%$ ではアミノ酸（タンパク質）の利用は ほとんど影響を受けないが，4\%ではやや低下するこ とが示された。しかしながら, 色落ちノリ添加 $4 \%$ 区 のタンパク質効率は対照区と差異が無かった。これは, タンパク質効率を求める式の特性から, 必ずしもタンパ ク質の利用効率を反映しないためだと考えられた。脂質 分解系酵素活性々糖新生系酵素活性の上昇々組織中の脂 肪含量の減少から, 適量のノリ添加 $(2 \%)$ によって脂 質のエネルギー源または糖質源としての利用が向上した と考元られる。しかしながら, 成長成績には栄養素利用 の変化が有意な差となって表れなかったため, 今後, よ り長期にわたる試験や飽食条件での検討が必要と思われ る。過剩の色落ちノリ添加（4％) では, タンパク質の 分解がやや抑制されているが, 脂質の分解よりも糖質や 脂質の合成が盛んになり, 利用されず血中にグルコース やコレステロールとして滞留してしまうことが示された。

以上, 本研究の結果からブリ当歳魚に抢いて, 色落ち ノリを飼料に添加することによって, 過剩量の添加（4 \%) では成長の低下が認められ, 代謝では脂質代謝系酵 素 (合成・分解), 糖新生系酵素抢よびアミノ基転移酵 素が影響を受けることが分かった。また，色落ちノリの ブリに打ける代謝系への作用は, 添加割合によって異な り, 添加 $2 \%$ では脂質分解々糖新生が促され, 添加 4 \%では脂質合成と糖新生が促進されることが確認され た。

\section{謝辞}

本研究は, JF 全国漁業協同組合連合会による養殖水 産物有効利用推進事業の一部として行われた。飼料の作 製は, 日本農産工業侏堀内三津幸氏と比留間聡氏に行っ 
て頂いた。また，本研究に関して中川平介名誉教授には 数々の有益なコメントを頂いた。この場を抢借りして皆 様に抢礼申し上げます。

\section{文献}

1）中川平介，笠原正五郎，宇野悦央，見奈美輝彦，明楽公 男. 養殖アユの抗病性に及ぼすクロレラ添加飼料の効 果. 水産増殖 $1981 ; 29: 109-116$.

2) Nakagawa H, Kasahara S, Tsujimura A, Akira K. Changes body composition during starvation in Chlorellaextract fed ayu. Nippon Suisan Gakkaishi. 1984; 50: 665671.

3）中川平介, 笠原正五郎, 杉山瑛之, 和田 功. クロダイ に対するアオサ添加飼料の効果. 水産増殖 1981; 32: 20 $-27$.

4）中川平介, 熊井英水, 中村元二, 笠原正五郎. 養殖八マ チに及ぼすクロレラエキス添加飼料の効果一II 血液性 状からみた負荷 (空気中放置) 抵抗力への効果. 水産増 殖 1982; 30: 76-83.

5）中川平介，笠原正五郎，宇野悦央，見奈美輝彦，明楽公 男. 養殖アユの血液性状, 体成分に及ぼすクロレラエキ 又添加飼料の効果. 水産増殖 1983; 30: 192-201.

6) Kalla A, Yoshimatsu T, Araki T, Zhang DM, Yamamoto T, Sakamoto S. Use of Porhyra speroplasts as feed additive for red sea bream. Fish. Sci. 2008; 74: 104-108.

7）中川平介, 熊井英水, 中村元二, 笠原正五郎. 養殖八マ チの血液・体成分に及ぼす藻類添加飼料の効果. 日水誌 1985; 51: 279-286.

8）浜渦敬三，山中弘雄. ブリに対する不稔性アオサ添加飼 料の効果. 水産増殖 $1997 ; 45: 357-363$.

9）浜渦敬三, 森岡克司, 高木雅成, 小畠 渥. ブリの体色 と肉質に及ぼす不稔性アオサ添加飼料の影響. 水産増殖 1997; 47: 89-95.

10) Watanebe T. Strategies for further development of aquaculture feeds. Fish. Sci. 2002; 68: 242-252.

11) Sá R, Pousão-Ferreira $P$, Olivia-Teles A. Effect of dietary protein and lipid levels on growth and feed utilization of white sea bream (Diplodus sargus) juveniles. Aquaculture Nutr. 2006; 12: 310-321.

12）示野貞男, 細川秀毅, 竹田正彦, 高山三圭, 福井章夫, 佐々木広治. 飼料脂質に対するハマチ肝臓酵素の適応. 日水誌 $1981 ; 47: 63-69$.

13) Shimeno S, Kheyyali D, Takeda M. Metabolic adaptation to prolonged starvation in carp. Nippon Suisan Gakkaishi 1990; 56: 35-41.

14）示野貞男, 竹田正彦, 高山三圭, 福井章夫, 佐々木広 治, 梶山英俊. 飼料炭水化物に対するコイ肝膵臓の適 応. 日水誌 $1981 ; 47: 71-77$.

15) Nakagawa H, Mustafa MG, Takii K, Umino T, Kumai H. Effect of dietary catechin and Spirulina on vitamin C metabolism in red sea bream. Fish. Sci. 2000; 66: 321326.

16) Frøyland L, Madsen L. Eckhiff KM, Lie $\varnothing$, Berge RK. Carnitine palmitoyltransferase I, carnitine palmitoyltransferase II, and Acyl-CoA oxidase activities in Atlantic salmon (Salmo salar). Lipids 1998; 33: 923-930.

17) Bilinski E, Jonas REE. Effects of coenzyme A and carnitine on fatty acid oxidation by rainbow trout mitochondria. J. Fish. Res. Bd. Canada 1970; 27: 857-864.

18) Fjermestead A, Hemre GI, Holm JC, Totland GK, Frøyland L. Effects of different dietary fat levels in cagefed Atlantic mackerel (Scomber scombrus). Eur. J. Lipid. Sci. Technol. 2000; 102: 282-286.

19) Official methods of analysis of the association of official chemists (ed. by Helrick, K.), $15^{\text {th }}$ edn, published by the association of the official analytical chemists, Inc., Arlington, Virginia, USA 1995.

20) Bligh EG, Dyer WJ. A rapid method of total lipid extraction and purification. Can. J. Biochem. Physiol. 1959; 37: 911-917.

21) Hashimoto T, Miyazawa S, Gunarso D, Furuta S. $\alpha-$ Amanitin inhibits the oxidation of long chain fatty acids in mouse liver. J. Biochem. 1981; 90: 415-421.

22) Moon T, Johnston IA. Starvation and the activities of glycolytic and gluconeogenic enzymes in skeletal muscle and liver of the plaice (Pleuronectes platessa). J. Comp. Physiol. 1980; 136: 31-38.

23) Glock GE, Mclean P. Further studies on the properties and assay of glucose 6-phosphate dehydrogenase and 6phosphogluconate dehydrogenase of rat liver. Biochem. J. 1953; 55: 400-408.

24）荻野浩志. 海苔成分の機能性の開発.「水産資源の先進的 有効利用法」(坂口守彦, 平田孝 監修)エスティーエス, 東京. $2005 ;$ 169-181.

25) Méton I, Fernández F, Baanate IV. Short- and long-term effects of refeeding on key enzyme activities in glycolysisgluconeogenesis in the liver of gilthead seabream (Sparus aurata). Aquaculture 2003; 225: 99-107. 